\title{
Blended Learning in Short Story Appreciation in High Schools of Surakarta-Indonesia
}

\author{
Main Sufanti' ${ }^{1}$, Agus Nuryatin ${ }^{2}$, Fathur Rokhman ${ }^{3}$, Herman J. Waluyo ${ }^{4}$ \\ ${ }^{1}$ Universitas Muhammadiyah Surakarta \\ ${ }^{2,3}$ Universitas Negeri Semarang \\ ${ }^{4}$ Universitas Sebelas Maret Surakarta \\ Corresponding email: $\underline{\mathrm{ms} 258 @ u m s . a c . i d}$
}

\begin{abstract}
Blended learning is a compounding between conventional and online learning system. In this industrial revolution 4.0 era, the learning system is an inevitability. This present study aims to describe the utilization of online media in selecting short stories, the inclusion of online learning elements in the short story appreciation, and the utilization of online media in the teaching and learning of literature appreciation. This descriptive-qualitative research employs information about the learning of short stories appreciation as its data. The data sources are in the form of informants i.e. Indonesian Language teachers, documents of teaching preparation, and processes of teaching and learning in the high schools. This current research uses questionnaire, observation, and document analysis as its data collection technique, further, an interactive technique to analyse the data. The result shows that (a) only $11 \%$ of the high school teachers in Surakarta prefer to choose online media as their basis to obtain the short stories; (b) the majority of the documents of the teaching preparation cite the internet as the medium or the learning resource, but are not reflected in the study; (c) the online media is used by the teachers to download short stories and applications on YouTube.
\end{abstract}

Keywords: Blended Learning, Short Story Appreciation, Information and Technology

\section{Introduction}

The Directorate of Senior High School Development, General Directorate of Primary and Secondary Education, Ministry of Education (2017) affirmed that in the $21^{\text {st }}$ century a learning should integrate the capabilities of the literacy skills, pieces of knowledge, skills, and attitudes, as well as the mastery of the technology. Hence, every single teacher's competency in technology is an obligation; further, it is an inevitability.

Ferguson

(http://www.bibliotech.us/pdfs/InfoLit.pdf)

claims that the literacy of information comprises five essential components i.e. Basic Literacy, Library Literacy, Media Literacy, Technological Literacy, and Visual Literacy. Technological literacy is one of the information literacies. Every single student should have their opportunity to runtechnology to construct a printed and online information. Conventional learning system (face-to-face) does not give them the experience to download or upload any information or student work as well as the online media.

Standing on the problem as stated above, this article aims to elaborate one of the innovations in the education system: blended learning. Blended learning is an modernization in learning that syndicates both conventional and online learning system. According to Prayitno (2015), Blended Learning is the combination of the conventional learning (face-to-face) and the application of information and communication technology. Douglas, Lang, \& Colasante (2018) states blended learning is an approach which combines the study which is in the form of online and face-to-face and improvement of the learning by combining the best of both approaches. Lalima \& Dangwal (2017) states that blended learning is the concept that includes teaching and learning that combines a face-to-face teaching and an ICT supported learning system.

Through this inventive learning system, it is able to be more flexible owing to its variations and innovations that can be carried out via the internet. Raharjo (2008) states that the internet is a source of learning as it provides many services of e-learning: virtual school, digital library, online learning resources. Moreover, the internet also aids as a communication tool such as e-mail and chat.

Setyorini (2015) argues that the advantages of the internet as the media of the learning system are: (a) the internet provides connectivity and broad range, (b) the access to internet is not limited by time, (c) the access 
through internet to search any teaching/learning materials is faster compared to offline searching, (d) the internet also provides interactive learning activities, (e) the internet can communicate with each other via chat or mailing list, and (f) the retrieval of information through the internet is much cheaper.

In this era of the industrial revolution in 4.0, teachers can no longer be the only resource, nonetheless they have to develop various learning resources both online and offline. A research result by Eryilmas (2015) concluded that the students have stated that they learn more effectively in an environment with a blended learning system. This environment design embraces online material sharing, forums, examination, text, picture, and video supported lesson summaries.

Blended learning can be applied in all subjects. The appreciation of the short story is one of the teaching material that is always existed in the high school curriculum. This teaching material is one of the materials taught in the Indonesian Language subjects and is one of the subjects examined nationally. Therefore, its existence is important to the innovation is highly needed. The integration of conventional class and the employment of online media take along an interesting learning, replete with learning resource, expanding experience, and increasing the students' and teachers' capability towards technology.

Based on the embellishment about the importance of the learning support, this research aims at (a) describing the utilization of online media in selecting short stories, (b) describing the inclusion of elements of online document preparation in the appreciation of the short stories in high school in Surakarta, and (c) describing utilization elements of online teaching and learning in the process of the appreciation of the short stories in high school in Surakarta.

\section{Research Method}

This is a descriptive qualitative research. The data are the form information of the utilization of the elements of online learning in the appreciation of the short story. The data sources are the Indonesian language teachers in high school associated with Teacher Education Consensus
Point (MGMP) of Indonesian language in Surakarta, preparation documentsof appreciation of short stories compiled by the teachers, and the teaching and learning process of the appreciation of short stories in high schools. The data were obtained through questionnaires, observation, and document analysis. In addition, the purposive sampling technique was used to select 9 teachers of Indonesian language from SMA Negeri 1 Surakarta, SMA Negeri 4 Surakarta, SMA Negeri 6 Surakarta, SMA Negeri 7 Surakarta, SMA Muhammadiyah 1 Surakarta, SMA Muhammadiyah 2 Surakarta, SMA MTA Surakarta, SMA Al Islam 1 Surakarta, dan SMA Pangudi Luhur Santo Yosef Surakarta. Finally, the data were analyzed through an interactive technique.

\section{Results and Discussion}

Based on the research objectives, it results in the utilization of online media in selecting short stories, the inclusion of online system in the document preparation, and the application of the online system in the teaching and learning process in SMA Surakarta.

\subsection{The Utilization of Online Media in Selecting Short Stories}

Based on the analyzed questionnaires, there are three techniques employed by the teachers in selecting short stories, i.e.: (1) selecting a short story from the textbooks, (2) selecting the short stories contained in the lesson book and any other sources, and (3) selecting the short stories from numerous sources and while ruling out the short stories in the textbooks.

The first technique is the teacher opts for a short story enclosed in the book text. There are seven of nine teachers (78\%) go for it. The textbooks are the foremost sources in selecting short stories, deprived of the addition of nearly other sources. They reasoned that the short story is accessible to all students, it is more programmatic, it has been usually read at home so the teaching-learning program is much easier, more practical, students are ready with the short stories taught, and equitable for all students. These reasons signpost that teachers strongly depend on textbooks as their main teaching sources.

The second technique is to opt a short story contained in the book lessons coupled with the short stories from other sources: 
magazine and newspaper. This is accomplished by one of nine teachers $(11 \%)$. The teacher has a reason: all students have had a short story in the book lessons that facilitate the learning process. In addition, the teacher chooses a short story that was published in newspaper and magazine in order to give exercise to deepen the knowledge of the students.

The third technique is to select the short story from a number of sources and the teachers often rule out the short story that is on the books of the students. Those assorted sources are such as newspapers, magazines, internet, and a collection of short stories. The data show that only one of nine teachers accomplish the way as the informant $(11 \%)$. They reasoned that (a) there are many sources of short story that can be employed as the teaching-learning program, therefore the teachers cannot rely on a single source only; (b) the teaching-learning material existed in the textbooks is limited, in fact, the students face the wide literary works outside; (c) the need of giving them various readings; (d) the effort to protect the students from an uneducated readings/materials.

The data show that the most of the teachers plump for the short stories presented in the textbooks. The textbooks are the printed Indonesian language textbook. Therefore, the teaching-learning material depends on the textbooks or students paper task applied by the teachers.

Build upon the revealed data, it can be asserted that few teachers integrate online media as their basis to develop their teachinglearning materials in accordance with the short story appreciation. Mostly, they utilize their textbooks as the main source of their teachinglearning process. However, in fact, Jeffrey, Mylne, \& Suddaby (2014) found that half of the teachers think that if there are too many online contents, it can be a problem since it gives a false sense of security to the students and makes them reluctant to attend classes. Also, it is felt that too many of the material has the potential to confuse the students.

The Internet, indeed, provides much convenience in choosing learning materials and effectivity. Bawaneh (2011) showed a positive relationship between the number of online files viewed by students, the number of online discussion messages posted by them, and their performance. However, to utilize the internet in the learning process, it is required that the teachers should have the adequate competence in technology. Syukur (2017) found that the common teachers of elementary, junior, and high school in Nganjuk have less proficiency in ICT.

\subsection{The Inclusion of Elements of Online Document Preparation}

The study found 10 documents of the teaching-learning preparation in the forms of the syllabus and lesson plan regarding appreciation of the short stories in high schools in Surakarta. The document analysis results in 5 documents $(50 \%)$ cite the internet as their medium of learning, 2 documents $(20 \%)$ cite the internet as their source of learning, and 3 documents $(30 \%)$ list no internet. Thus, it can be concluded that $70 \%$ documents of the preparation list the internet (online element) as the media or learning resource.

The inclusion of the internet as the media or learning resource in the documents is not followed by the further description in the other components, for example, on the steps of learning or evaluation. The overall analysis of the components in the document does not find the technique, time, or blurb about exploiting the internet in learning. Henceforth, the word "internet" in this document is not vibrant applied in the learning yet.

The analysed data can express that in terms of the document preparation of the teachers, the majority of teachers have the idea that the internet should be the media or the learning resource. This thinking is in accordance with the principle of learning that suits to Permendikbud number 22 the Year 2016 about the standard process of primary and secondary education. The principle is that the learning should be based on the various learning resources and should utilize the information and communication technologies to improve the efficiency and effectiveness of the learning process.

Even if the teachers have their forethought to take advantage of the internet in learning, but have yet to draw up the planning of teaching by utilizing the internet in detail. This shows that the high school teachers in Surakarta have yet to implement the term internet properly. These findings have the same condition with the research results in 
Nganjuk that is the majority of the primary school teachers rarely employ the internet, while the junior high school teachers never utilize the internet (Syukur, 2017).Similarly, Royana (2012) found that most of the utilization of the ICT by teachers of physical education in high school in Sleman in learning of physical education is considered low.

The conditions in those two provinces on Java, Indonesia are different to the conditions in elsewhere. Vaugan (2014) found that 96\% students from Mount Royal University Ethics apply the digital technology particularly to access the online course materials and to communicate with the instructors and any other students.

\subsection{The Utilization of the Online Element in the Process of Teaching and Learning}

Based on the results of the interviews and observations, the informants state that they use online media to download the short stories to be used as the teaching-learning materials. The short story distributed to the students is under the title "Gadis Kecil yang Menghafal Lagu Kebangsaan" by Fitriyani. It can be downloaded from page Kliping Sastra Indonesia

at https://id.klipingsastra.com/2014/12/.

In addition, the teachers download several You tube application in the form of a video from the internet. These videos have a common theme or story with the selected short story. The video is used as an introduction to the learning. Based on the observation, the teachers aired a video entitled "Bersama dalam Perbedaan" produced by the Walagri Aksara. This video can be downloaded at https://www.youtube.com/watch? $\mathrm{v}=\mathrm{gSZ7gI}$ LY888. The next video called "Singkawang Ditetapkan sebagai Kota paling Toleransi di Indonesia" produced by DAAI TV. This video can be downloaded at https://www.youtube.com/watch?v=BCvmF5J vyew. Those videos have their common theme with the short story: diversity and tolerance.

It shows that in the learning of appreciation of the short story in SMA Surakarta, the internet is only used as a media and learning resource. Lalima \& Dangwal (2017) explained that the blended learning integrates conventional class, students interaction with course content, peer group interaction, group discussion and exchange of ideas, accessing the e-library, virtual classroom, online assessment, etuitions, accessing and maintaining educational blogs, webinars, expert lectures in viewing YouTube, online learning through videos and audios, and virtual laboratories. If it is associated with the concept of Lalima \& Dangwal (2017), the appreciation of the short story in the investigated high school have not covered all elements of the blended learning leaning, but at least it conceals the elements of face to face, student interaction with course content, accessing and maintaining educational blogs, and online learning through videos and audios.

The study found only a few teachers who utilize the internet as a variation of face-toface learning. Blended learning is not a selection of the teachers in making learning innovations and variations yet. These findings give the understanding that teachers have not felt the urge to make use of the internet in the teaching-learning program. The majority of teachers feel that using the textbooks as a learning resource in learning of appreciation of short stories is already enough.

\section{Conclusion}

Based on the analysis above, this study can be concluded as follows: (a) only $11 \%$ of the high school teachers in Surakarta prefer to choose online media as their basis to obtain the short stories; (b) the majority of the documents of the teaching preparation cite the internet as the medium or the learning resource but are not reflected in the study; (c) the online media is used by the teachers to download short stories and applications on YouTube presented at the introduction of the learning.

\section{References}

Bawaneh, S.S. 2011. "The Effects of Blended Learning Approach on Students' Performance: Evidence from a Computerized Accounting Course". International Journal of Humanities and Social Science, 1 (6): 63-69.

Douglas, K. Lang, J., \& Colasante, M. 2014. "The Challenges of Blended Learning Using a Media Annotation Tool". Journal of University Teaching \& Learning Practice. 11 (2): 1-19.

Ferguson, B. Information Literacy, A Primer for Teachers, Librarians, and other 
Informed People. A Free Ebook.

Jeffrey, L., Milne, J., \& Suddaby, G. 2014. "Blended Learning: How Teachers Balance the Blend of Online and Classroom Components". Journal of International Technology Education: Research, 3 (13): 121-140.

Lalima \& Dangwal, K.L. 2017. "Blended Learning: An Innovative Approach". Universal Journal of Education Research, 5 (1): 129-136.

Prayitno, W. 2015. "Implementasi Blended Learning dalam Pembelajaran pada Pendidakan Dasar dan Menengah". LPMP D.I Jogja Kemdikbud.

Raharjo, P. 2008. Pemanfaatan Internet dalam Pembelajaran. Jakarta: Pusat teknologi Informasi dan komunikasi Depdiknas.

Royana, F. 2012. Pemanfatana teknologi
Informasi dan Komunikasi (TIK) oleh Guru Pendidikan Jasmani di di SMA negeri Se-Kabupaten Sleman dalam pembelajaran Pendidikan Jasmani . Thesis S1

Setyorini, R. 2015. "Pemanfaatan Internet sebagai Implementasi ICT dan Sarana memotivasi belajar Sastra Siswa". Prosiding Workshop Nasional Pendidikan "Pengembnagan ICT dalam Pembelajaran".

Syukur, I. A. 2017. "Profesionalisme Guru dalam mengimplementasikan Teknologi Informasi dan Komunikasi di Kabupaten Nganjuk". Jurnal Pendidikan dan Kebudayaan, 20 (2): 200-2010. 